\title{
Knowing Your Ancestors: A Survey of Bahamians' Knowledge of Their Progenitor's Names
}

\section{Nicolette Bethel \\ Jessica Minnis \\ William J. Fielding ${ }^{1}$ \\ The College of The Bahamas}

\begin{abstract}
An on-line survey of 1,447 persons indicate that almost all participants (98.4\%) knew both their biological father and mother. However, few (7.6\%) knew the names of all their great grandparents. The direct female relations on the maternal side were more likely to be known than other similar relations on the paternal side. This knowledge of names confirms the matrifocal nature of Bahamian families and indicates the need for families to take steps to preserve their own history, so as to provide a sense of identity.
\end{abstract}

\section{INTRODUCTION}

Family relationships are important in The Bahamas. One of the first questions posed on meeting a new person is to determine their family background: "Oh you must be related to so-and-so", is a common first topic of conversation (Glinton-Meicholas, 1998). However, in a society where, of 43,297 households with children, 14,117 (32.6\%) were headed by single females and 7,471 $(17.3 \%)$ were headed by females who had never married (Plumridge \& Fielding, 2009), just how well do we know our immediate blood relations? A fundamental way of knowing a person is to know their name. Without a name, people are just faces. Without names, we cannot know who we are.
If we are to be aware of who we are as a people, we must first know who we are as individuals.

This research project was carried out with the consent of the Office of Research, Graduate Programmes and International Relations of The College of The Bahamas.

\section{METHOD}

An on-line survey was devised in the spring of 2012 which asked if the respondent knew the first name and surname of their relations as far back as the great-grandparents on both their mother's and father's side. Knowledge of their mother's maiden name was not specifically requested, but this was implied through the names (forename and surname) of

\footnotetext{
${ }^{1}$ Nicolette Bethel, School of Social Sciences; Jessica Minnis, School of Social Sciences and William J. Fielding, Director of Planning, The College of The Bahamas, P.O. Box N-4912, Nassau, Bahamas.

Acknowledgments: We are grateful to the students of The College of The Bahamas who collected the data. Corresponding author: wfielding@cob.edu.bs

How to cite this article in APA (6th ed.) style: Bethel, N., Minnis, J., \& Fielding, W. J. (2012). Knowing your ancestors: A survey of Bahamians' knowledge of their progenitor's names. The International Journal of Bahamian Studies, 18, 1-5. https://doi.org/10.15362/ijbs.v18i0.171
}

CN. Bethel, et al., 2012. Journal compilation @ The International Journal of Bahamian Studies, 2012. 
grandparents.

College of The Bahamas students were invited to complete the on-line survey and to solicit 25 other participants using a snowball technique.

This resulted in 1,712 subjects participating. The data were cleaned, to remove respondents who were not born in The Bahamas and also those who were not Bahamian citizens. The responses for knowing the first and surname of relations included a not sure response. These responses were replaced by no for the purposes of analysis. Respondents who failed to answer the questions regarding their parents were deleted. Respondents who answered most of the questions regarding relations, but not necessarily all, were included and their blanks replaced by no responses. This resulted in 1,447 responses which were complete with respect to relational information.

\section{RESULTS}

Demographics of respondents

A minority of respondents, were male $(34.6 \%)$, and the modal age group was $18-27$ years (74.6\%). $43.3 \%$ were students at the College of The Bahamas.

\section{Named blood relations}

Only one person did not know the names of either parent, and $1.5 \%$ knew the name of only one parent. Of the 22 persons who did not know the name of one parent, 20 of these parents were the fathers. The intergenerational memory dropped from $98.4 \%$ knowing both parents, to $60.4 \%$ knowing all four grandparents and 7.6\% knowing all eight grand-grandparents.

Female relations were more likely to be known than their corresponding male relations in all generations back to that of great-grandparents, as shown in Table 1.

Older respondents and females were more knowledgeable about their ancestors than younger respondents and males. Those in the 18-27 year age group were less likely than those aged over 27 to know all four grandparents, $58.5 \%$ compared with $66.3 \%$, $\chi^{2}(4, n=1,436)=13.2, p=.01$. Female respondents were more likely than male respondents to know all four grandparents, $62.5 \%$ compared with $56.4 \%, \chi^{2}(4, N=1,447)$ $=24.6, \mathrm{p}<.001$ and less likely to know none of their eight great grandparents than males, $32 \%$ compared with $40 \%, \chi^{2}(8, N=1,447)=$ $20.9, \mathrm{p}=.007$. No other statistically significant differences associated with age group or sex were found concerning knowledge of parents, grandparents or great grandparents.

Table 1

Respondents knowing first name and surname of blood relations back to their great-grandparents. $(N=1,447)$

\begin{tabular}{|c|c|c|c|c|c|c|c|}
\hline \multicolumn{4}{|c|}{ Mother } & \multicolumn{4}{|c|}{ Father } \\
\hline \multicolumn{4}{|c|}{$99.8 \%$} & \multicolumn{4}{|c|}{$98.5 \%$} \\
\hline \multicolumn{2}{|c|}{ Grandmother } & \multicolumn{2}{|c|}{ Grandfather } & \multicolumn{2}{|c|}{ Grandmother } & \multicolumn{2}{|c|}{ Grandfather } \\
\hline \multicolumn{2}{|c|}{$93.5 \%$} & \multicolumn{2}{|c|}{$87.4 \%$} & \multicolumn{2}{|c|}{$81.8 \%$} & \multicolumn{2}{|c|}{$70.8 \%$} \\
\hline $\begin{array}{c}\text { Great- } \\
\text { Grandmother }\end{array}$ & $\begin{array}{c}\text { Great- } \\
\text { Grandfather }\end{array}$ & $\begin{array}{c}\text { Great- } \\
\text { Grandmother }\end{array}$ & $\begin{array}{c}\text { Great- } \\
\text { Grandfather }\end{array}$ & $\begin{array}{c}\text { Great- } \\
\text { Grandmother }\end{array}$ & $\begin{array}{c}\text { Great- } \\
\text { Grandfather }\end{array}$ & $\begin{array}{c}\text { Great- } \\
\text { Grandmother }\end{array}$ & $\begin{array}{c}\text { Great- } \\
\text { Grandfather }\end{array}$ \\
\hline $52.2 \%$ & $36.4 \%$ & $27.9 \%$ & $22.8 \%$ & $23.3 \%$ & $16.3 \%$ & $16.4 \%$ & $15.3 \%$ \\
\hline
\end{tabular}

Note: Most known relations in bold. 


\section{DISCUSSION}

The study was limited to participants who had access to the Internet. Since Internet access is not universal in The Bahamas (McKenzie, 2012), the results of this survey may represent only higher income homes (Bahamas Department of Statistics, 2004), and so introduce bias in the results. This limitation should be noted when interpreting the results.

The data would appear to confirm that despite the absence of biological fathers in many homes, fathers are still known, at least by name, to their children. This provides the basis for the child to have a relationship of some sort with their father.

While $87 \%$ of school age pupils lived with their mother, only $50 \%$ lived with their father.

When there was no father present, grandparents appeared to fill that void (10\% of pupils lived with mothers and grandparents but no father), but this did not happen when the mother was absent (only 1\% of pupils lived with a father and grandparents and no mother; as shown in Figure 1).

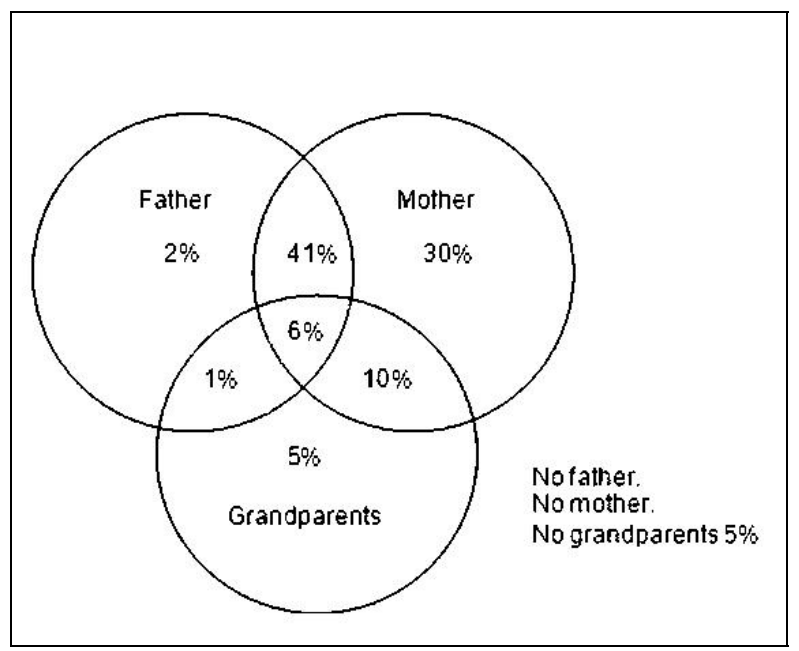

Figure1: Composition of Grades 7, 9 and 11 student households (Bahamas. Ministry of Health, Health Information Unit, 2001).

The centrality of the grandparent in the household is not unusual in the Caribbean context, as Chamberlain (2003) has indicated. Chamberlain goes so far as to suggest that this tendency, acknowledged across the Caribbean, may be evidence of "widely held beliefs relating to lineage and continuity" (2003, p. 69). Our study, however, suggests that this may be an exaggeration, as our findings indicate that respondents' knowledge about their ancestors is shallow. Although many children may have been brought up under the influence of grandparents (McCartney, 1976), our data suggest that it is the maternal grandmother who is the most known of the grandparents. The grandparents, of either sex, on the father's side, are even less well-known than the grandfathers on the maternal side. This is probably a consequence of the father not being a resident in the same household in which a child may have resided.

In the literature on Caribbean family structure, the concept of matrifocality is central (e.g. Clarke, 1966; Smith, 1956). In other words, "a woman in the status of 'mother' is usually the de facto leader of the group, and the husband-father ... is usually marginal" (Smith, 1956, p. 223). The Bahamian household is no exception to this model. Bahamian families are both structurally matrifocal, in that the father is not physically present in the home, and functionally matrifocal, meaning that even when the father is present, "mothers perform the majority of the tasks in the home, including that of providing economic support for their families" (Bethel, 1993, p. 13).

This present study indicates the depth of this matrifocality, in that only the great grandmother on the maternal side was known to the majority of respondents. This suggests that not only are current families matrifocal in structure and function, but that this matrifocality is perpetuated over time. Our results show that family history is also more firmly situated in female respondents, which may also be another reflection on the matrifocal nature of the family. 
These findings are in keeping both with classical studies done on Caribbean family structure and also with recent studies conducted on African-Caribbean families both in the Caribbean region and in the wider diaspora. Navara and Lollis (2009) observe that "mothers, and often grandmothers, hold a central position in ... families" (p. 448), that "their children and grandchildren saw these women as gatekeepers to Jamaican [cultural] traditions" (p. 448), and that, when it came to transmitting family stories, "female members of the Jamaican immigrant family were potentially exposed to these stories more often than the males" (p. 450). Similarly, in Cuba, Härkönen (2010) observes that "whereas my informants were usually knowledgeable about how many siblings they had on their mother's side and maintained firm relationships with them, they were often unaware of how many siblings they had on their father's side" (p. 63), and that "a person's most important kin are usually the matrilateral grandmother and the mother's siblings and their children" (p. 62).
Few respondents knew all their great grandparents. This suggests that it is important for Bahamians to keep good family records so that they may know their roots beyond two generations. The advent of inexpensive cameras and computer software for labeling and storing pictures with names, date, and place, means that there are easily accessible means by which families can preserve their relational history, either digitally, or by printing pictures for an album. As noted in a previous study, $4.9 \%$ of student households had no family photograph album (Fielding, 2008), and this puts those families without such a book, or similar collection, at risk of losing touch with their history, and ultimately their identity. The fact that proportionately more younger respondents than older respondents were less knowledgeable about their ancestors makes the preservation of family knowledge a matter of urgency if they are to maintain their family history.

\section{REFERENCES}

Bahamas Department of Statistics. (2004). Bahamas living conditions survey 2001. Nassau, Bahamas: Author.

Bahamas Ministry of Health, Health Information Unit. (2001). [Bahamas youth health survey]. Unpublished raw data.

Bethel, N. (1993). Bahamian kinship and the power of women. (Unpublished master's thesis). University of Cambridge, England.

Chamberlain, M. (2003). Rethinking Caribbean families: Extending the links. Community, Work \& Family, 6(1) 63-76. doi:1080/1366880032000063905

Clarke, E. (1966). My mother who fathered me. London, England: Allen \& Unwin.

Fielding, W. J. (2008). Attitudes and actions of pet caregivers in New Providence, The Bahamas, in the context of their American counterparts. Anthrozoös, 21(4), 351-361.

Glinton-Meicholas, P. (1998). The 994 breakfast. Nassau, Bahamas: Guanima.

Härkönen, H. (2010). Gender, kinship and lifecycle rituals in Cuba. Suomen Antropolgi: Journal of the Finnish Anthropological Society, 35(1) 60-73.

McCartney, T. (1976). Bahamian sexuality. Nassau, Bahamas: TimPaul Publications.

McKenzie, N. (2012, February 27)._GDP boost from raising Bahamas' $60 \%$ net. The Tribune. Retrieved from http://www.tribune242.com/news/2012/feb 
/27/gdp-boost-from-raising-bahamas-60net-access/

Navara, G. S. \& Lollis, S. (2009). How adolescent children of African Jamaican immigrants living in Canada perceive and negotiate their roles within a matrifocal family. Family Process, 48(3), 441-458. doi:10.1111/j.1545-5300.2009.01294.X

Plumridge, S. J., \& Fielding, W. J. (2009). Domestic violence in college student households, New Providence, The Bahamas. The College of The Bahamas Research Journal, 15; 45-54. Retrieved from http://journals.sfu.ca/cob/index.php/files/is sue/view/23

Smith, R. T. (1956). The negro family in British Guiana: Family structure and social status in the villages. London, England: Routledge \& Kegan Paul. 